\title{
ADDRESS AT THE SERVICE OF THANKSGIVING FOR THE RT. HON. LORD DENNING, O.M. ${ }^{*}$
}

\author{
The Rt.Hon. Lord Bingham of Cornhill ${ }^{* *}$
}

Lord Denning is the best known-known and best-loved judge in the whole of our history.

There have over the centuries been judges of strong character, powerful intellect, great learning, courage, wisdom, compassion, eloquence, robust commonsense. All these qualities Lord Denning had in abundance. But he had something more: a unique gift of human warmth which endeared him to everyone who knew him and many who did not.

The story of Lord Denning's upbringing in Whitchurch, with his parents, his sister and his four brothers, has been so vividly and movingly told by him that it is familiar to us all. But one thing in particular is striking. Throughout his long life he remained unfailingly true to the values, beliefs, habits and tastes of his early years. He was a devoted member of the Anglican Church, loving its worship, liturgy and language. He answered to an unbending sense of duty. He had an indefatigable capacity and inexhaustible relish for hard work. He had a love of his country both deep and proud. He had a passionate love of the English countryside, particularly the chalk uplands of North Hampshire and the magical valley of the Test. He felt an instinctive respect for the continuity of our institutions and traditions and for authority, if not always for the authorities. $\mathrm{He}$ practised the virtues of thrift, sobriety and plain living. He had an unaffected simplicity of speech and bearing. He believed, profoundly, in the brotherhood of man and the worth of individual human beings. He was contemptuous of the "fugitive, the trivial and the mean." The late Victorian principles by which he governed his life are unfashionable today; and it is not surprising that his lifelong adherence to them should have given ammunition to his critics in a later and more permissive age.

\footnotetext{
* Westminster Abbey, Thursday, 17 June, 1999

** Then, the Lord Chief Justice of England \& Wales, presently the Senior Law Lord of Appeal in Ordinary.
} 


\section{THE DENNING LAW JOURNAL}

This is not the place and this is not the occasion to attempt any assessment of Lord Denning's legal legacy. But nor, I think, would he wish us to ignore the great work to which, during his now unrepeatable thirty-eight year tenure of high judicial office, he devoted his life. There was little in the law which over that time he did not touch; and little that he touched which he did not adorn. In the vast body of cases which he decided, two chords in particular are dominant. The first is fairness, a term which cannot (I believe) be accurately translated into any other language: faimess in the treatment of the citizen by the state, of the litigant by the judge, of the applicant by the tribunal, of the consumer by the supplier, of the tenant by the landlord, of the customer by the bank, of the deserted wife by her husband, of the member by the trade union or the profession, of the patient by the hospital and the doctor, of the party injured by a careless statement or act by the author of the injury. The second chord is freedom: freedom of the press; freedom of the person; freedom of mind and conscience; freedom from executive interference; freedom under the law.

If wrapped in legal jargon, with an occasional dash of Latin, all these things may sound technical and abstruse and remote from the humdrum realities of everyday life. But in his mouth they never did. Lord Denning's judgments were rooted not in discussion of abstract jurisprudential principle but in the vivid experience of recognisable men and women. It was this human dimension, coupled with a distinctive literary style, which gave his judgments their unmistakable and very personal quality. We all have our favourites. I cannot forbear to quote four of his:

"Old Peter Beswick was a coal merchant in Eccles, Lancashire. He had no business premises. All he had was a lorry, scales and weights..."

"It happened on 19 April 1964. It was bluebell time in Kent. Mr and Mrs Hinz had been married some ten years, and they had four children, all aged 9 and under. The youngest was one. Mrs Hinz was a remarkable woman...."

"Broadchalke is one of the most pleasing villages in England. Old Herbert Bundy, the defendant, was a farmer there. His home was at Yew Tree Farm. It went back for three hundred years. His family had been there for generations. It was his only asset. But he did a very foolish thing. He mortgaged it to the bank. Up to the very hilt..." 


\section{MEMORIAL ADDRESS}

"To some this may appear to be a very small matter, but to $\mathrm{Mr}$ Harry Hook it is very important. He is a street trader in the Barnsley market. He has been trading there for some six years without any complaint being made against him; but nevertheless; he has now been banned from trading in the market for life. All because of a trifling incident..."

The peculiar genius of Lord Denning was perfectly matched to the need of the hour. "When Tom and I were young," wrote Lord Devlin, "the law was stagnant." In Lord Hailsham's words, "It seemed almost as if Our Lady of the Common Law had gone into a decline....." The age of creation appeared to have gone. That of literalists, slavish adherents of precedent and quietist acceptors of the status quo appeared to have succeeded; and the glory of the common law appeared to have been extinguished forever. That the law was aroused from its torpor was not, of course, the work of one court or one judge. The credit must be much more widely shared. But in any roll of the great emancipators Lord Denning would be assured of an honoured place, probably at the head of the list. For he brought a new, adventurous and imaginative vision to bear. He was more concerned with the intention of a statute than with its precise terminology. He was not overly respectful of precedent. He was prepared to entertain unorthodox arguments if they appeared to lead to what he saw as justice. He did not shrink from novelty. "What is the argument on the other side?" he asked in one case, and answered:

"Only this, that no case has been found in which it has been done before. That argument does not appeal to me in the least. If we never do anything which has not been done before, we shall never get anywhere. The law will stand still while the rest of the world goes on: and that will be bad for both."

The secret of his attraction to the legal profession and to the general public was, as Lord Devlin suggested, the belief that he opened the door to the law above the law. He had, to the end, an almost uncanny insight into the thoughts and values of his fellow-countrymen.

To the advocate he was the perfect judge: courteous, unintimidating, openminded, very quick, self-deprecating, devoid of pomposity. He seemed genuinely interested in every case, however, arid; he was warm and encouraging to counsel, particularly the untried. Under his benign but exacting inquiry all 


\section{THE DENNING LAW JOURNAL}

advocates gave of their best. Unlike some other judges, he could demolish an argument he judged to be false without needlessly humiliating its author. And for all his interest and patience he was never indecisive; there was never any doubt about who had won.

His longevity could on occasion be a problem. I recall one case in which my argument depended heavily on an observation of Viscount Simon, speaking for a unanimous seven-member House of Lords in 1942. I warmed to my theme. But the Master of the Rolls interrupted. "Oh," he said, "but Lord Simon was very sorry he ever said that. He told me so." But sometimes his encyclopaedic knowledge of the cases, or his vivid imagination, would come to the aid of an advocate cowering under the assault of his opponent or of Lord Denning's judicial colleagues. Like all great judges he was of course, on occasion, inconsistent and unpredictable. All depended on his, sometimes very personal, perception of where the merits lay and what justice required. But that made the hearing all the more absorbing. No wonder the Bar loved him. No wonder that his colleagues embarked on so many hazardous journeys under his leadership. No wonder that his exchanges with litigants representing themselves, conducted on his side in his broadest Hampshire burr, were the stuff of legend. No wonder that he inspired such loyalty among those who worked for him.

For five days a week, over a continuous period of more than twenty years, Lord Denning presided in the Master of the Rolls' court, giving the first judgment in every single case, usually as soon as the argument had ended. It was an intellectual, and also a physical, achievement which will never be rivalled. His energy, his interest and his appetite were unflagging. If the beleaguered advocate were tempted to inquire, at 4 o'clock on a Friday afternoon, whether the court might think it a convenient moment to rise, he would be disappointed.

I have so far said nothing of the private man. His devotion to the memory of his first wife Mary, who died so tragically and so young, is a matter of record. $\mathrm{He}$ was a very proud and very affectionate father of Robert, who followed in his footsteps with great distinction to Magdalen College, Oxford, and a great patriarch of his extended family. His attachment to his second wife Joan is perhaps best expressed in a letter written on her death after nearly forty-seven years of married life:

"I feel it is really an occasion for thankfulness for a long and happy life - but for me it is all sadness at the loss of her so dear to me." 


\section{MEMORIAL ADDRESS}

It would scarcely be possible to list the bodies to which, over the years, he gave his loyalty and lent his energetic support. They would certainly include Magdalen College, Oxford, Birkbeck College, London and the University of Buckingham; the Inns of Court, particularly Lincoln's Inn, his parent Inn, and the Law Society; the Lawyers' Christian Fellowship; the Cheshire Homes, Cumberland Lodge and Outpost Emmaus; the Magna Carta Trust, the Public Record Office, the Historical Manuscripts Commission; the Magistrates' Association; the British Institute of International and Comparative Law; the English Association; the National Association of Parish Councils; the National Marriage Guidance Council; the Draper's Company; Queen Elizabeth College, Greenwich; the City of London. But he still found time to arbitrate about sugar cane in Fiji and bananas in Jamaica. He still accepted the Prime Minister's invitation to report on the Profumo Affair, a task accomplished between June and September of 1963; many years later he presided at a dinner in Lincoln's Inn to celebrate the outstanding service of Mr Profumo, to Toynbee Hall, an event which testifies to the stature of both men. At an age when most men look for leisure, Lord Denning turned author, publishing books in each of his last four years in office, books valued by those who have them not only for their contents but also for their very personal dedications. And throughout his term as Master of the Rolls he travelled the world, tirelessly and repeatedly, giving lectures and addresses, receiving honorary degrees, making friends and establishing a rapport with the young of five continents which few men of any age have ever enjoyed. To those who expect judges to be cold, formal, bloodless and pedantic he was a revelation. The respect and affection he inspired, particularly in the countries of the Commonwealth, was indeed extraordinary: I recall meeting a Guyanese advocate who practised from Denning Chambers in Georgetown and who had christened his eldest son Alfred Thompson. Last year saw the opening of Denning House in Calgary, Alberta. Many other examples could be given, in this country and around the world. For all these services alone, Her Majesty's appointment to the Order of Merit, unique for a professional judge, would have been well-earned recognition.

We are privileged to remember Lord Denning as an unforgettable human being whose hundredth birthday we recently celebrated with pride and pleasure. But we also remember him as a great judge and it is as a great judge that he will take his place in history. Not all his judgments, of course, will stand the test of time; some, indeed, were cut down in the pride of their youth; others were raked by academic grapeshot. But more, many more, left an indelible imprint on the living law of our country, and the spirit which inspired all these judgments will endure. He saw the law not as a code of rules, but as a collection of human stories, each 


\section{THE DENNING LAW JOURNAL}

with a moral; not as a fetter, but as a source of freedom; not as an unwelcome but inescapable response to the ills of society, but as a means of providing that justice upon which good government and social harmony fundamentally depend. He invested the art of the advocate and the role of the judge with a new nobility. He always looked forward, never back. He sought to build, not to pull down.

Some well-known lines of Wordsworth provide, I think, an appropriate epitaph:

"Enough, if something from our hands have power

To live, and act, and serve the future hour;

And if, as toward the silent tomb we go,

Through love, through hope, and faith's transcendent dower, We feel that we are greater than we know." 